\title{
NÅGRA CENTRALA JUDISKA BEGREPP \\ I DE FINLANDSSVENSKA RELIGIONSBÖCKERNA FÖR GRUNDSKOLAN*
}

\author{
Karl-Johan Illman
}

\section{Inledning}

Avsikten med min undersökning är att visa, hur vissa termer och begrepp används och definieras i de skolböcker i religion som används i våra finlandssvenska grundskolor. Jag valde i förväg ut femton sådana termer, varav vissa sedan $\mathrm{i}$ presentationen kommer att sammanföras till grupper. Även om urvalet enligt min egen åsikt kanske inte visade sig vara helt tillfredsställande med hänsyn till materialets art, har jag beslutat bibehålla dem i stället för att göra nämnvärda justeringar. Jag förutsätter, att termer som används huvudsakligen $i$ undervisningen om bibeln äger stor relevans också för den bild av judendomen som ges. Termerna är följande:

1. Landet, dess namn, utsträckning, löfte om, villkor, exil/återvändande;

2. Uttâget, dess innebörd som firningsämne för den judiska påsken;

3. Förbundet, utkorelsen, villkoren, hålla/bryta förbundet;

4. Folket, dess namn förr och nu;

5. Framtidshoppet, gudsriket, Messias, Människosonen etc.;

6. Bibeln, den judiska och den kristna, omfång, innehåll etc.;

7. Lagen, betydelsen och funktionen hos den judiska toran;

8. Fariseer, skriftlärda och andra jämförbara judiska grupper;

9. Jesus som jude, hur kommer det fram? Hans motståndare och vänner;

* Reviderad version av föredrag, hållet vid den tredje nordiska kongressen i judaistik i Åbo 11.6.1985. Föredraget sändes på remiss till läroboksförfattarna av vilka flera kom med värdefulla synpunkter, som jag försökt beakta.
10. Paulus som jude, hans förhållande till judar och judekristna;

11. Den kristna missionen i dess begynnelseskede;

12. Judiska institutioner: tempel, synagoga etc. i NT:s tid och senare;

13. Antijudaism och antisemitism: förföljelser, polemik, kristendomens roll, rasismen;

14. Holocaust, vad var det? Dess orsaker och följder;

15. Sionismen och staten Israel: historisk bakgrund, läget idag; palestinierfrågan etc.;

I fråga om materialet har jag stannat för ett "längdsnitt" av vad som läses i de finlandssvenska grundskolorna idag. Jag har avstått ifrån att ta med gymnasiet, eftersom två andra föredrag behandlar detta material. ${ }^{1}$ Vidare har jag av tidsskäl inte kunnat ta mig an motsvarande finskspråkiga böcker; ej heller har jag kunnat göra jämförelser med äldre material. Eftersom skolböckernas utformning bestäms av gällande läroplaner, deras målsättningar och av därpå baserade handledningar har jag tagit med dessa i undersökningsmaterialet, som är följande:

Grundskolans läroplansbetänkande II. Läroplan för läroämnena. Kommittebetän-

kande 1970:A5. Helsingfors $1970 . \quad$ Lp

Religion. Evangelisk-luthersk religionsundervisning. Handledning 22. Helsingfors 1972.

B. \& J. Vikström, Vår kristendomsbok I. Första årskursen. Vasa 1983

B. \& J. Vikström, Vår kristendomsbok II. Andra ärskursen. Vasa 1983

G. Aldener, N.G. Engström, E. Sigfrids, Bibeln berättar. Religionskunskap för årskurs 3 och 4. Vasa 1980.
Åk3-4

förkortning

$\mathrm{Hl}$

$\AA \mathrm{k} 1$

$\AA \mathrm{k} 2$ 
S. Heimdahl, Bibeln berättar. Studiebok för åk 3. Vasa 1980.

Åk3s

S. Heimdahl, Bibeln berättar. Studiebok för åk 4. Vasa 1980.

Åk4s

G. Aldener, N.G. Engström, E. Sigfrids,

Budskapet och budbärarna. Religionskunskap för åk 5 och 6. Vasa 1981.

S. Heimdahl, Budskapet och budbärarna. Studiebok âk 5. Vasa 1979.

G. Björkstrand, Religion 7. Lärobok i religion för grundskolans årskurs 7. Vasa 1982.

G. Björkstrand, Religion 8. Lärobok i religion för grundskolans ärskurs 8. Vasa 1981.

G. Björkstrand, Religion 9. Lärobok i religion för grundskolans årskurs 9. Vasa 1982.
$\AA ̊ \AA 5-6$

$\AA \mathrm{k} 5 \mathrm{~s}$

$\AA ̊ \mathrm{k} 7$

$\AA \mathrm{k} 8^{2}$

$\AA \mathrm{k} 9$
I min genomgång av materialet går jag från årskurs 1 stegvis till årskurs 9, för att få en överblick av i vilket skede eleverna konfronteras med en viss term, ett begrepp eller en sak och hur det sker. Materialet disponeras i enlighet med mina utgångstermer (1-15). När jag för bedömningen av vad som står $\mathrm{i}$ böckerna finner anledning att konsultera läroplanerna och handledningen gör jag så. De allmänna målen och principerna för grundskolans religionsundervisning vill jag dock förutskicka. ${ }^{3}$

Målen är följande (Lp, 202):

Målet för den evangelisk-lutherska religionsundervisningen är att befrämja elevernas religiösà, etiska och sociala utveckling och på så sätt befrämja mognandet av deras personlighet genom att

1. göra eleverna förtrogna med den kristna traditionen såsom den framför allt uppenbaras i Bibeln samt i den kristna trons innehăll och i dess olika uttrycksformer: i bönen, gudstjänsten och i livet,

2. ge eleverna en bild av det kristna livet så som det framträder i deras egen kyrka samt även i den ortodoxa kyrkan och andra kristna samfund; man strävar till att eleverna skulle se gemensamma drag i de olika kristna kyrkorna,

3. orientera eleverna även i icke kristna religioners traditioner samt lära dem att respektera människor med annan religiös övertygelse,

4. uppfostra eleverna till kärlek till nästan och dess förverkligande i olika slag av samlevnad såväl inom små som stora samfund,

5. göra eleverna förtrogna med sådana sociala regler, som är en förutsättning för mänsklig samlevnad och om vilka människor med olika världsåskådning kan enas,

6. lära de unga att iaktta det nutida samhällets etiska problem och söka lösningar, som skulle öka varje individs människovärde inom olika levnadsområden, samt
7. sträva till, att varje klass och skola skulle bilda en gemenskap där varje elevs människovärde erkännes oberoende av prestationsnivå och där man vårdar sig om elevernas mentala hälsa och befrämjar den personliga integriteten.

Beträffande "andra religioner och religiösa samfund" heter det (Lp, 221): "Man bör sträva till att behandla icke-kristna religioner $i$ en varm positiv anda utgående från deras egna förutsättningar och försöka finna gemensamma drag i olika religioner". Det konstateras dock, att inom den tid som står till buds kan andra religioner inte ens $\mathrm{i}$ grundskolans högstadium behandlas särskilt ingående (Lp, 222), men man bör göra så gott man kan med hjälp av aktiverande grupparbete.

Ur judaistisk synpunkt är det intressant att se hur man betraktar förhållandet mellan GT och NT. I betänkandet från 1970 skymtar ställvis en traditionell kristen åsikt fram som på ett ställe formuleras så här: 'I Gamla testamentet förekommer visserligen berättelser om att Gud straffade människorna för deras ondska genom olika slags yttre olyckor, men dessa uppfattningar strider mot vad Jesus lärde om Gud. Enligt Nya testamentet älskar Gud alla människor oberoende av hurudana de är. Nya testamentets gudsbild bör vara den förhärskande $\mathrm{i}$ undervisningen ända från början, och den bör verka som ett kriterium, enligt vilket man väljer stoffet för undervisningen ur Gamla testamentets berättelser"' (Lp, 218).

I handledningen heter det: "Man försöker göra Bibelns berättelser begripliga för barn utan att dock omforma dem men undviker [...] vid samtal om de etiska uppfattningar som rådde på Gamla testamentets tid, att beröra sådant, som är religionshistoriskt rätt men strider mot den fostran man vill ge" $(\mathrm{Hl}, 8)$.

Denna kontrastering av "testamentena" har ett visst samband med det faktum att vi har att göra med konfessionell religionsundervisning. Vad detta är, definierar handledningen bl.a. på följande sätt:

Såsom läroämne i en skola, som bekostas av samhället, innebär en s.k. konfessionell (till något trossamfunds lära anpassad) religionsundervisning i stort sett en anslutning till uppfattningarna inom ifrågavarande trossamfund. Det är inte fråga om att skolan därigenom aktivt skulle verka fốr att väcka eller stärka elevernas medvetande om sitt medlemskap, men inte heller om att den skulle motverka någonting sâdant... Ett drag som för närvarande kännetecknar kristendomen är strävan till samarbete och samförstånd över bekännelsegränser- 
na. Om man i skolans religionsundervisning beaktar detta innebär det, att man i stället för att betona skiljaktiga uppfattningar bör framhålla gemensamma drag. Man kan naturligtvis inte förtiga de olika uppfattningarna, men om de ställs mot en historisk bakgrund och jämförs med varandra - något som är möjligt särskilt på högstadiet - kan eleverna förstå olikheterna. ( $\mathrm{Hl}, 6 \mathrm{f}$.

I fråga om andra religioner upprepar handledningen vad som sades $i$ betänkandet med tilllägget att dessa "inte bör framställas som bakgrund för missionsarbetet". Och vidare:

Man försöker skildra religionernas utveckling och nuvarande ställning med hjälp av äkta material. Mâlet för undervisningen $\mathrm{i}$ främmande religioner är att lära eleverna förståelse och tolerans inför olikheter och ge dem en vidgad kännedom om världen. Det är således även fråga om en fostran till internationell förståelse. (HI, 12).

Efter den här kort skisserade bakgrunden går jag över till redovisningen av resultaten. Av både praktiska och innehållsliga skäl kommer jag därvid att sammanföra vissa av de frågor jag ställt till gemensamma underavdelningar.

\section{Resultat}

\section{Frågan om landet}

Att hitta rätta benämningar på "landet" så att de passar till de epoker som behandlas hör som bekant inte till det lättaste. Vad man kunde vänta, är att landet

- kallas Kanaan när det gäller den äldsta gammaltestamentliga epoken;

- kallas Palestina när det handlar om Jesu tid;

- kallas Israel när det gäller vår egen tid.

Så här fördelas benämningarna också i stora drag, men avvikelser finns. En väntad avvikelse dyker upp när man diskuterar det israelitiska kungadömet och dess delning. Då uppstår behovet av att tala om "Israels rike" och "Juda rike", men det sker bara en gång (Åk 3-4, 35) explicit $\mathrm{i}$ den tryckta texten och skrivs in i studieboken ( $\AA \mathrm{k} 3 \mathrm{~s}, 8)$. Både Samuels mor Hanna ( $\mathrm{k}$ 2, 28) och David (Åk2, 30) sägs ha bott i Israel. Daniel däremot var en pojke från Palestina $(\AA \mathrm{kl}, 17)$. Att namnet tidigare, när invandringen skedde, var Kanaan, men "nu", dvs på Jesu tid (?) är Palestina sägs direkt ut $(\AA ̊ k 1,101)$. Treans studiebok förutsätter dessutom korsords- svaret att "romarnas nya namn på Kanaan" var Palestina (Åk3s,63).

Anknytningar till nutiden sker upprepade gånger, och då används som sagt Israel; dock även här finns ett undantag, när det $\mathrm{i}$ treans grundbok heter: "Låtsas att du făr resa till $\mathrm{Pa}$ lestina. Vad vill du se och göra där" ( $\AA$ k3-4, 47). Jag tolkar denna inkonsekvens så, att det är fråga om en resa i tiden lika mycket som i rummet.

Kartorna är här av visst intresse: samma karta ges i första och andra årskursen ( $\AA \mathrm{kl}, 62$; Åk2,37) utan något namn på landet, men väl med namnen Galileen, Samarien, Judeen. De här områdena förklaras senare vara "landskap" ( $\mathrm{k}$ 3s, 51) eller "landsdelar" ( $\mathrm{k}$ 4s, 35). Den tredje kartan eleverna möter är den välbekanta "Palestina på Jesu tid" med alla de då aktuella landsdelarna. Jag hänvisar till det bekanta sakförhållandet att "Palestina" blir landets namn först ca 100 år efter Jesu tid (efter Bar Kochbaupprorets krossande år 135). Detta blir eleverna inte upplysta om; men det kanske inte bör betraktas som någon större brist, eftersom bibelforskarna använder namnet "Palestina" för fullt om både gammal- och nytestamentlig tid. Orsaken härtill är väl att bibelforskningen och den bibliska geografin och arkeologin uppkom under en tid då Bibelns land tillhörde det ottomanska riket, varför benämningen var både praktisk och naturlig. Trots vissa inkonsekvenser i skolböckernas användning av benämningarna, finner jag här ingen allvarlig olägenhet.

Bortsett från geografiska och historiska aspekter har ju frågan om "landet" också tydliga religiösa och känslomässiga aspekter, och - när det gäller det moderna Israel - även politiska sådana. Här kan sägas, att positiva konnotationer ges:

$$
\begin{aligned}
& \text { - "det land där Jesus bodde" ( } \AA \mathrm{kl}, 101) \\
& \text { — "Landet där Jesus föddes" (rubrik, Åk2,36; rubrik } \\
& \AA \mathrm{k} 3-4,116) \\
& \text { - "löftets land" (inom citationstecken, } \AA \text { k 3-4, 21) } \\
& \text { _- "Det heliga landet" ( } \AA \mathrm{k} 3-4,46 \mathrm{f} \text {; } \AA \mathrm{k} 7,22) \\
& \text { - "Jesu hemland" ( } \AA \mathrm{k} 3-4,47 ; \AA \AA \mathrm{k} 5 \mathrm{~s}, 22)
\end{aligned}
$$

Sammanfattningsvis kan sägas, att landet får ganska mycket utrymme. I lärarhandledningen sägs att "ämnesområdet Palestina" behandlas i årskurs 1 för att ge en referensram åt "ämnesområdet Bibelns berättelse om Jesu födelse" (Hl, 8). Samma referensram behövs sedan upprepade gånger, när bibliska teman berörs, och de berörs i större eller mindre utsträckning i alla årskur- 


\section{SUMMARY}

Some important Jewish concepts in teaching materials of the Swedish-speaking elementary school in Finland

Thematic study of Judaism appears on the curriculum only in the 7th of the 9 grades in elementary school. To this rather short course one has to add much of the material on the Bible, especially what is said about "Judaism at the time of Jesus". Here a whole series of key concepts turn up already in the first two grades. In this connection much relevant and also correct information is given. However, also the supposed old contradictions between e.g. the concept of God and the ethics of the Old and the New Testament respectively, appear already in the teaching plans and teacher's guides regulating the materials and their use. This can be seen as a consequence of the fact that religious instruction is confessional, that is, it should correspond broadly speaking to the views held by the church in question. However, one should not overstress the impact of this Lutheran perspective.

This study was carried out with the help of fifteen concepts, of which those of "the land", "the law", "Scribes and Pharisees", "anti-Semitism", "Zionism and the State of Israel" were the most crucial ones. The traditional contrast between "law and grace", "the Pharisees and Jesus" etc. were there to be sure. On the other hand, Jesus was, if not explicitly, nevertheless implicity identified as a Jew. Many positive things were said about the Old Testament law, too. But when it came to comparison between Jesus and his fellow Jews, the traditional opposition was maintained. What this writer found erroneous was the assumption that Jesus' claim to be the Messiah (if he claimed that) was presented as blasphemy and that it should have been enough for the death penalty according to Jewish law. Also the tendency to lump together all Jewish groups as involved in the trial of ser. Man har helt riktigt funnit att denna referensram är både nödvändig och troligen också intressant för de flesta eleverna. Både de sakliga upplysningarna av historisk och geografisk art och de känslomässiga konnotationerna ges med tanke på ämnets komplicerade karaktär enligt min mening på ett tillfredsställande sätt.

\section{2-3. Uttåget, utkorelsen och förbundet}

De här frågorna behandlas tämligen kortfattat. Israeliternas uttåg ur Egypten omnämns givetvis ( $\AA \mathrm{k} 3-4,14 ; \AA \mathrm{k} 4 \mathrm{~s}, 38)$ och i samband därmed att judarna firar påsk till åminnelse härav:

påsk betyder passera, gå förbi. Påsken var judarnas största högtid. På påskkvällen samlas fortfarande alla judiska familjer till en påskalammsmåltid. Den yngsta frågar: Varför är denna natt olika all andra nätter? Därefter berättar familjefadern om uttåget ur Egypten. (Åk3-4, 14)

Till festen och påskmåltiden återkommer man senare i samband med en översikt av alla tre vallfartsfesterna ( $\AA \mathrm{k} 3-4,48 f$.) och i samband med behandlingen av Jesu sista måltid med lärjungarna ( $\mathrm{k} \mathrm{k} 4 \mathrm{~s}, 59)$. Slutligen finns uttåget kort behandlat $\mathrm{i}$ sjunde årskursen $(\AA \mathrm{k} 7,52)$.
Sinai-förbundet framställs dels som ett förnyande av förbundet med Abraham, dels som medförande något nytt. Först nämns de tio budorden, som liknas "vid livets spelregler" ( $\AA$ k3-4, 19) eller "trafikmärken" ( $\AA \mathrm{k} 3 \mathrm{~s}, 18 \mathrm{f}$.). Sedan sägs att israeliterna genom Mose också fick "många andra lagar" (jfr nedan fråga 7). Efter intåget $\mathrm{i}$ Kanaan har israeliterna börjat dyrka kanaaneiska gudar och därmed glömt lydnaden mot första budet ( $\AA \mathrm{k} 3-4,24 \mathrm{f}$.).

Förbundet mellan Gud och hans folk tas på nytt upp i $\AA \mathrm{k} 7$, där ca 5.5 sidor ägnas åt judendomen. Här sägs bl.a. ( $\AA \mathrm{k} 7,32)$ :

Mose, som levde på 1200-talet f.Kr., är den egentliga grundaren av judendomen genom att han gav folket lagen och genom att ett förbund slöts mellan Gud och hans folk. Sedan dess har judendomen varit en nationalreligion. Under de följaṇde århundradena kallade Gud genom profeterna folket att hålla fast vid förbundet. Men folket gick sin egen väg. Man fick därför tillbringa c. 50 år $\mathrm{i}$ babylonisk fångenskap (586-538 f.Kr.).

Något senare kommer åk7 in på utkorelsen. Av "judarnas trosbekännelse" framgår att "man tror att det finns en enda Gud, som har utvalt Israel till sitt egendomsfolk" (Åk7, 34.36). Frågan varför besvaras med en hänvisning till 5 Mos. 7:7-8 ["för att Herren älskade er"] 
Jesus, without any effort to make distinctions, is well known but hardly correct. I find here an uncritical attitude to the way the Gospels present the trial. The simple fact that not all the different and partly contradictory views in the Gospels themselves can be correct has not caused the authors to choose from the historically more probable ones. In addition to this, there was in the exercise books a strong tendency towards memorizing simple "facts", as if they really were facts. This sometimes took the rather unpleasant form of comparisons between the Pharisees' caring about the law and Jesus' concern for the poor and oppressed. Here we find the old caricatures in spite of the suffering they have caused the Jewish people and of what Biblical and Judaic research has contributed to today's view of Judaism at the time of Jesus.

The scant information about anti-Semitism, Zionism and the State of Israel was mostly correct - the exceptions are easy to correct. It would be desirable, however, that more attention be given to e.g. the Holocaust, since this would help young people to see where anti-Semitism led, however difficult it might be to explain. In the face of all the new information about antiSemitism and hatred of "aliens" broadcast everyday, one should not hesitate to take up these themes. This would contribute to educating young people in "internationalism" which is also one of the explicit goals of religious instruction in our primary schools.

My investigation ends with the suggestion that the books for grades 3-6 be removed and substituted with new textbooks. Since a reconsideration of the plans for instruction in the elementary schools is on its way, I find the time for this suggestion to be most appropriate. I also wish that co-operation between educators and scholars in the respective fields whould be regarded normal and desirable already in planning and preparing the teaching materials for the elementary school. My contacts with the authors of the textbooks in question and with other educators have been most encouraging.
( $\AA \mathrm{k} 7,37)$. I samband med en presentation av bibelns berättelsestoff heter det: "Syftet med berättelserna är att visa att Gud har utvalt Israel till sitt folk för att han vill frälsa världen. För Israel är det viktigt att inte svika den uppgiften" $(\AA ̊ k 7,51)$.

Omdömet om detta knapphändiga material blir att vi här på det hela taget får en positiv och riktig bild av uttåget, utkorelsen och förbundet, låt vara starkt förenklad.

\section{Folket}

De två vanligaste namnen på folket är inte oväntat israeliterna och judarna. Några varianter förekommer givetvis också:

— "Israels folk": $\AA \mathrm{k} 1,101.129 ; \AA \mathrm{k} 2,26.48$; $\AA \mathrm{k}$ 7,50 ;

— "Israels barn": Åk1, 129; Åk3-4,10.20.21. ("hebraism")

— "Israel": Åk3-4,58 (bibelcitat) men också "Israels botdag" Åk3-4,49.

Adjektiven "israelitisk" och "judisk" förekommer givetvis också. Liksom ifråga om landet kunde man vänta sig, att benämningarna, skulle svara mot epokerna, dvs. gammal-, nytes- tamentlig och modern tid. Så är det också i stort sett, men inte utan undantag. Sålunda används varianten "Israels folk" både om folket på GT:s tid $(\AA \AA k 7,51 f)$ och på NT:s tid $(\AA ̊ k 1,101)$.

Intressant är kanske när "judarna" kommer in i bilden. Går man kursvis genom materialet, möter eleverna det första gången i Pilatus fråga till Jesus: "Är du judarnas konung?" ( $\AA$ k2,77), vilket kan bero på att bibeltexten ger det här. I årskurs 3 får eleverna läsa, att alltifrån uttåget ur Egypten "firar judarna påsk till minne" av detta uttåg ( $\AA$ k3-4, 14). Kronologiskt exaktare är upplysningen om att Cyrus/Kores "lät judarna återvända till sitt land" ( $\AA \mathrm{k} 3-4,35)$ och att "judarna" under fångenskapen i Babylon hade längtat till Jerusalem ( $₫$ k3-4,36). Efter återkomsten härskade "andra folk över judarna" ( $\AA$ k3-4,35). Härigenom får man intrycket att exilen skulle kunna uppfattas som en tidsgräns. $\AA ̊$ andra sidan säger studieboken till åk3 att "judarnas lag var något ovanligt bra på den tiden", varmed man får intrycket att författaren snarare tänker på Mose tid än på den tid "Lagen" som skriftsamling kodifierades. Också i fortsättningen talas det om "judarna" och deras "lag" ( $\AA \mathrm{k} 3 \mathrm{~s}, 69-75)$ - men snarast som en bakgrund till Jesu verksamhet, vilket skulle förklara användningen av denna beteckning för folket.

$\mathrm{Nu}$ bör vi ställa frågan om vad som sägs om 
judarna, bortsett från rent objektiv information, samt hur det sägs. Många positiva ting:

— "Jesus tillhörde Israels folk"; han "fick läsa om sitt folk" i skolan (Åk1, 101);

- "att offra var israeliternas sätt att tillbedja och tacka Gud" (Åk3s, 17); "Gud hjälpte sitt folk" ( $\mathrm{k} 3-4,15 f$.$) ;$

— "Judarnas lag var något ovanligt bra på den tiden. De flesta folk hade inga skrivna lagar alls" ( $\AA$ k3s, 69); "Trots att judarna var rädda för Gud, kände de att Gud brydde sig om dem. På det sättet skilde sig judarnas gudssyn från andra folks. Judarna hade upptäckt goda egenskaper hos Gud" ( $\AA$ k3s, 70);

- "Judarna var ensamma om att införa en speciell vilodag i veckan, sabbatsdagen... Också Jesus helgade sabbatsdagen..." ( $\AA \mathrm{k9}$, 75).

Mot dessa positiva saker måste man sedan ställa det negativa. När det blir tal om Samarien och "samariterna" heter det att dessa "föraktades av judarna, därför att de flesta av dem dyrkade Gud på ett annat sätt än judarna. Det var ett blandfolk" (Åk3-4, 47). Samma sak kännetecknar judarnas inställning till publikanerna, om vilka det heter att de var "tullmän i romarnas tjänst. De brukade ta högre avgifter än de hade rätt till och var därför hatade av judarna" (Åk3-4, 62). Som exempel på en sådan publikan tas Sackeus. Boken uppmanar eleverna att läsa Luk 19:1-10, "hur Jesus bemötte Sackeus, som judarna föraktade" ( $\AA$ k3-4, 172). Femte årskursen får genast i början läsa: "Tulltjänstemännen kallades publikaner. De var illa ansedda och fruktade. Judarna fick inte vara tillsammans med dem. En annan grupp av människor, som judarna föraktade, kallades syndare. Till dem hörde brottslingar, men också sjuka och fattiga. De fromma judarna ansåg, att dessa människor hade brutit mot Guds vilja" ( $\AA$ k5-6, 8). Sackeus tas upp pånytt $(\AA \mathrm{k} 5-6,14)$. "Judarna" figurerar igen på ett negativt sätt om Jesu botande av den lame mannen, som återberättas enligt Joh 5,118. Även konstaterandet att judarna "inte ville ha något med samariterna att göra" dyker upp igen $(\AA \mathrm{k} 5-6,23)$. Litet senare har man samlat ihop de "föraktade" till en grupp: "Av evangelierna framgår att t.ex. samariter, publikaner och syndare var föraktade av de fromma judarna." (Ak 5-6,38). Detta konstateras strida mot kärleksbudet, enligt Jesus. Antitesen mellan detta och judarnas "Du skall älska din nästa och hata din ovän" enligt Matt 5:43-45 återges. Övningsboken stöder minnet genom att fråga: "Vilka tre grupper av människor blev utstötta ur samhällets gemenskap på Jesu tid?’ (Åk5s, 41).
Här vill jag skjuta in två korta kommentarer. 1. Samtidigt som man hamrar in vilka grupper "judarna föraktade" och varför, glömmer man att påpeka, att två av dem, nämligen "publikanerna och syndarna" själva var "judar". Det handlar alltså om en inomjudisk motsättning. 2. Bokens författare tycks också vara omedvetna om att antitesen beträffande kärleksbudet är konstruerad, eftersom ordet "Du skall älska din nästa och hata din ovän" inte har kunnat beläggas i judiska källor. Läroboken fastslår likväl, att "ett av de gamla buden" lydde just så här (Åk5-6, 40).

"Judarna" omnämns ytterligare som fiender till Paulus: de "ville döda" honom ( $\mathrm{k}$ 5-6, 85.98.95). Intressant är också att när den "gyllene regeln" presenteras, så sker det antingen som Jesu egen sammanfattning av sitt budskap (Åk5-6, 39f.), eller också som något som finns i olika varianter inom de stora världsreligionerna, med undantag av judendomen! (Åk7, 39). Hillels berömda motsvarighet omnämns inte med ett ord. Varför?

\section{Framtidshoppet}

Här rör det sig om ett omfattande problemkomplex, som berör bl.a. de messianska titlarna och gudsrikesföreställningarna i GT och NT, samt givetvis judendomen. Det traditionella kristna greppet att ta fram messiasförväntningarna i GT och visa hur Jesus uppfyllde dem kännetecknar i stort sett framställningarna. Delvis tränger en interpretatio christiana in $\mathrm{i}$ presentationen av GT-materialet. När det blir tal om profeternas förutsägelser om Messias heter det på ett ställe: "De talade om, att det av Davids släkt skulle födas en son, som Gud skulle sända till jorden för att hjälpa och frälsa människorna" (Åk3-4, 39). Som beläggställen citeras Jes 9:2.6 och Sak 9:9, där det ju inte finns något uttryck om att konungen skall "sändas till jorden".

Allvarligare blir det när man försöker spela ut olika messias-förväntningar mot varandra: "Somliga ansåg, att Messias skulle bli en jordisk konung, som skulle fördriva folkets fiender. Andra menade att han skulle bli en fridens konung" ( $\AA$ k3-4, 36). Studieboken förklarar dessa alternativ så att Jesus måste välja mellan att göra som de flesta väntade, dvs. "störta Romarriket och själv bli en jordisk konung", eller "bli en konung som Gud ville: komma med frid och hjälp till olyckliga människor". Härefter frågas, vilket alternativ Jesus valde: "Att härska - att 
hjälpa" (Åk3s, 60). Det betänkliga är inte, menar jag, att man framhåller att Jesus måste välja. Snarare är det detta att "jordisk konung" spelas ut mot "fridens konung". Den utan tvekan jordiske Messias som omtalas i Jes 9 kallas ju dock "Fridsfurste"! Den här sidan kommer klart fram först $i$ årskurs 7, när det som en judisk lära anges: "Messias skall komma och skall upprätta ett jordiskt fredsrike med centrum i Jerusalem" ( $\AA \mathrm{k} 7,41)$. Ännu mera problematisk blir framställningen, när det hävdas att "När Jesus då påstod, att han var Messias, fällde man dödsdomen. Rådsherrarna och översteprästerna menade att han bara var en människa. Om en människa påstod sig vara Messias, hädade hon, och straffet för sådant var döden" ( $\AA \mathrm{k} 3-4,69 f$.). Sådana tolkningar av orsaken till dödsdomen över Jesus återkommer ofta. Förutsättningarna är då att Messias=Guds son=Gud. Vi vet, att de här förutsättningarna snarare är kristna än judiska. Och om Jesu anspråk vet vi historiskt sett nästan ingenting. $\mathrm{Om}$ Jesus utgav sig för att vara Messias skulle den naturligaste tolkningen ha varit att han gjorde anspråk på att vara just en jordisk konung och att detta skulle ha varit anledningen till romersk dödsdom snarare än en judisk. Här följer läroboksförfattarna emellertid evangeliernas tendentiösa framställning att lägga skulden på judarna och frita Pilatus. Endast så kan Jesu eventuella messias-anspråk framställas som hädelse. Jag anser, att läroboksförfattarnas okritiska övertagande av de i sig ganska motstridiga versionerna av passionshistorien har försatt dem i så stora svårigheter, att de har måst påstå saker som vi inte vet och på vissa punkter direkt konstruera sakförhållanden, som historiskt sett är ohållbara.

Det blir anledning att återkomma härtill i avsnittet om lagen.

\section{Bibeln}

På denna punkt finns det ett antal positiva utsagor om GT som den judiska bibeln och Jesu bibel. Redan i första årskursen läser eleverna:

När Jesus var pojke, gick han i skola. Där fick han läsa om sitt folk. Han läste många bok-rullar. Samma böcker finns i Bibeln. De kallas Gamla testamentet. Där får man veta hur Gud hjälpte sitt folk och talade till dem. Gamla testamentet var Jesu bibel. $(\AA \mathrm{kl}, 101)$.

I andra årskursen får man ytterligare läsa, att Psaltaren också var Jesu bönbok $(\AA \mathrm{k} 2,30)$, i fjärde att Jesus undervisades $i$ ''folkets heliga skrifter" ( $\AA \mathrm{k} 3-4,122)$, i femte att de första kristna läste ur GT:s skrifter och sjöng ur Psaltaren, "judarnas sångbok" (Åk5-6, 76). Sjunde årskursens specialavsnitt om judendomen börjar med orden:

Judendomen är moderreligion till två andra religioner, nämligen kristendomen och islam. Det är också den religion som står kristendomen närmast. Gamla testamentet (GT) utgör helig skrift för båda religionerna. (Åk7, 32).

Trots dessa och andra påpekanden om att GT utgör en förbindelselänk mellan judendom och kristendom, saknas det inte strävanden att peka på skillnader mellan GT och NT, vad gäller gudsuppfattning och etik. Studieboken för årskurs 5 ställer frågan: "Vilken del av bibeln, Gamla eller Nya testamentet, visar på ett klarare sätt, hurdan (sic!) Gud är?”' ( $\AA$ k5s, 7). Detta svarar mot en information i grundboken, att Jesus i tal och liknelser visar "klarare än Gamla testamentets profeter, hurdan Gud är" ( $\AA$ k3-4, 7). Jag nöjer mig i detta sammanhang med att hänvisa till läroplanens kontrastering av GT:s och NT:s gudsuppfattning (Lp, 218) och handledningens kontrastering av etiken $\mathrm{i}$ de båda "testamentena" (Hl, 8), som jag ovan har citerat. Man har här nöjt sig med att följa traditionella mönster.

Totalintrycket av sättet att presentera GT och dess judiska ursprung är dock enligt mitt förmenande övervägande positivt.

\section{Lagen}

Jag har redan preliminärt berört den brännbara frågan om "lagen". Eleverna konfronteras med den $\mathrm{i}$ tredje årskursen på ett mjukt och positivt sätt:

Tio Guds bud kan liknas vid livets spelregler. De hade inte bara getts åt Israels barn vid Sinai berg. De gäller för alla tider. Budorden är inte fiender till livet, utan tvärtom hjälper de oss att fă ett rätt förhăllande både till Gud och våra medmänniskor. Därför kan vi kalla buden livets egen lag. Den som bryter mot Guds lag, skadar både sig själv och andra. $(\AA \AA$ k3-4, 19)

Studieboken förliknar dem som nämnts vid "trafikmärken" ( $\AA \mathrm{k} 3 \mathrm{~s}, 18-21)$. Inte heller konstaterandet att israeliterna genom Mose också fick "många andra lagar än tio Guds bud" kan 
uppfattas såsom ett negativt påpekande. Det fortsätter nämligen:

Mose ville att rättvisa skulle råda. Mose lag stadgade bland annat att man skulle sörja för att fattiga och gamla fick hjälp. Mose är en av de främsta lagstiftarna som har funnits. $(\AA \mathrm{k} 3-4,20)$

Jag kan ännu påminna om studiebokens konstaterande, att "judarnas lag var något ovanligt bra på den tiden. De flesta folk hade inga skrivna lagar alls" ( $\AA$ k3s, 69).

Jesu laglydnad kommer fram bl.a. vid parafrasen av Mk 1:44, när han uppmanar den nyss botade spetälske mannen: "gå bort och visa dig för prästerna som man brukar göra. Och du skall offra till Herren som det står i lagen" ( $\AA$ k3-4, 57), varvid det förklaras att lagen är lika med Mose lag. Också berättelsen om den rike mannen (Mk 10:17-22) ger anledning till en hänvisning till lagen av Jesus: "Varför kallar du mig god? Ingen annan än Gud är god. Buden känner du..." ( $\AA$ k5-6, 22). I dessa fall har jag dock på känn att det är bibeltexterna som ger oss Jesu positiva inställning till lagen, snarare än någon medveten avsikt hos författarna.

Femte årskursens studiebok finner det dock befogat att påpeka att

— det "efter vårt sätt att se" också var "små saker" som bestämdes i Lagen, t.ex. frågor om klädedräkten; här hänvisas till.stadgarna om hörntofsarna i 4 Mos 15:38-39, men också till deras funktion;

- man kunde drabbas av ett hårt straff för en liten förseelse: här hänvisas till 2 Mos 35:2 som stadgar dödsstraff för överträdelse av sabbatsbudet. Det påpekas dock, att en sådan disproportion mellan brott och straff gällde "förr i tiden"/"bland alla folk". (̊̊k3s, 69f.)

På det hela taget var dock Mose lag något ovanligt bra, som sagt. I fjärde årskursen konfronteras eleverna ånyo med fall där lagen stipulerar dödsstraff: berättelsen om äktenskapsbryterskan (Joh 8, ̊̊k3-4, 129) och Jesu förmenta hädelse (Matt 26:57-68, ̊̊k3-4, 147/Åk4s, 60). Studieboken ger därvid följande alternativ:

- I judarnas lag bestämdes fängelsestraff/dödsstraff för hädelse.

- Att säga sig vara Gud/bryta mot tredje budet kallades hädelse.
Om den muntliga lagen sägs mycket litet. I studieboken för tredje årskursen ges något illavarslande alternativfrågan: "de äldstes stadgar var fariséernas/Mose tillägg till Lagen" (Åk3s, 68). I femte årskursen definieras en lagklok med "den som kunde Mose lag och de förklaringar till lagen, som kallades de äldstes stadgar" (Åk5-6, 23). I sjunde årskursen, där ordet tora första och enda gången används om Moseböckerna, sägs: "Vid sidan av GT står Talmud. Talmud tillkom på 400-talet e.Kr. Där har man samlat alla regler och föreskrifter både för gudstjänsten och livet". Bortsett från århundradet som förefaller att vara en kompromiss mellan tiden för den palestinensiska och den babyloniska talmuds tillkomsttid, är det inte mycket att invända häremot. Om judarna på 1800-talet, sägs det litet förenklande att de delade sig i två huvudinriktningar: ortodoxa och liberala. $\mathrm{Om}$ dessa heter det: "De ortodoxa anser att man måste rätta sig efter alla de gamla bestämmelserna i Talmud när det t.ex. gäller sabbaten, omskärelsen, ren och oren mat. De liberala vill anpassa religionen efter samhällets och tidens krav" (Åk7, 33). En lätt värdering till förmån för de liberala kan utläsas här. Tydligare blir värderingen dock när beskrivningen av den traditionella judendomen $\mathrm{i}$ åttans kurs kontrasteras mot Jesu budskap i Bergspredikan: "Jesu allmänna råd skiljer sig mycket från de detaljerade föreskrifter som judarna hade. Man har räknat ut att en jude hade 613 bud att iaktta, varav 365 var förbud. Vanligt folk kunde inte hålla dem alla och därför uppstod skarpa gränser mellan fromma fariseer som följde alla föreskrifter noggrant, och fattiga människor som bara kunde tänka på det allra viktigaste... Jesus kom med ett evangelium (=ett glatt budskap) till dem som inte kunde uppfylla alla de många buden. Också de hade rätt att vara saliga, dvs. lyckliga och glada... Jesus kom för att de fattiga och förtryckta skulle få en chans. Han talade till dem för vilka det religiösa livet med alla sina föreskrifter hade blivit främmande. De åter som dömde och föraktade andra fick höra stränga ord om sin kärlekslöshet" (Åk8, 9f.). Det här citatet kanske framför allt visar, att så fort läroböckerna kommer in på en beskrivning av "evangelium", kommer "judendomen" på traditionellt sätt att få utgöra den mörka bakgrunden mot vilken evangeliets ljus fås att lysa så klart som möjligt. I andra sammanhang har man råd att fälla positiva omdömen om "lagen". 


\section{Fariseer och skriftlärda}

Redan andra årskursens barn får veta, att "de skrift-lärda blev arga och beslöt att döda Jesus för att han sa att han var Guds son" $(\AA \mathrm{k} 2,75)$. Judas och de soldater som han visade vägen förde Jesus till "överste-prästen Kaifas. Han ville att Jesus skulle dö". Därefter bar det i väg till lands-hövdingen Pilatus, som "såg att Jesus var snäll. Men han ville vara vän med folkets ledare. Därför dömde han Jesus till döden" ( $\mathrm{k}$ 2, 77). Av det här får man uppfattningen att det först var de skriftlärda och sedan, den avgörande natten, översteprästen, som ville ha Jesus dödad. De skulle kunna kallas "folkets ledare", vars vilja Pilatus s.a.s. mot bättre vetande biföll. De var därmed också Jesu fiender. Var kommer då fariseerna in i bilden? I tredje årskursen heter det:

Fariséerna var namnet på en grupp fromma män bland judarna på Jesu tid. De var mycket noga med att hålla lagen... Fariséerna ansåg att allt som inte godkändes $i$ lagen och de äldstes stadgar var synd, och den ville de hålla sig borta ifrån. Det var därför de kallades fariséer. Farisé betyder nämligen "den avskilde" eller "den avsöndrade". Människor som inte ville följa buden och stadgarna var orena, menade fariséerna. De föraktade sådana människor och ville inte umgås med dem... För fariséerna var det t.ex. förbjudet att på en vilodag gå mer än en kilometer, att bära en börda, att lösa upp en knut, att sy två stygn, att skriva två bokstäver, att tända upp eld och släcka ett ljus. (Åk3-4, 60).

Här tillägger studieboken ytterligare informationen, att "alla fariséer tillhörde en fariséerförening. Sådana fanns det många av i Palestina. De flesta fariséer var hantverkare till yrket". Vidare: "De skriftlärda var de förnämsta bland fariseerna" (Åk3s, 67), alltså ett slags ärkefariseer. Men inte nog härmed. Studieboken vill på sitt vanliga sätt befästa kunskapen genom alternativ:

- Fariséerna var noga med att hålla Lagen och de äldstas stadgar/hjälpa sin nästa.

- Fariseerna tyckte, att allt som inte stod i Lagen och de äldstes stadgar var onödigt/synd.

- Farisé betyder den som är god/den avskilde.

- Alla som inte kunde eller ville följa Lagen och Stadgarna var orena/oförståndiga, tyckte fariséerna.

- Sådana ville man hjälpa/föraktade man.

- Fariséerna måste hålla $613 / 113$ bud och förbud.

- Många av buden gällde kärleken till nästan/vilodagen.

- Fariséerna följde buden för att synas av människor/ tjäna Gud. (Åk3s, 68)

Det sista baserar sig på grundbokens återgi- vande av berättelsen om fariseen och publikanen (Matt 23:6-8). Det som faller i ögonen i den här citerade serien, är väl framför allt tendensen $i$ valet av alternativ. Dessutom har man omkonstruerat grundbokens påstående, att "allt som inte godkändes $i$ lagen och de äldstes stadgar var synd" till det orimliga "allt som inte stod i Lagen och de äldstes stadgar". Grundboken för sin del fortsätter med att påpeka, att "alla fariséer inte var fientligt inställda mot Jesus" och hänvisar till Joh 3:1-2 ( $\AA$ k3-4, 61), dvs. berättelsen om Nikodemus nattliga besök. Men det framstår som ett undantag från regeln. Boken fortsätter med berättelsen ur Mark 3, om Jesu besök i en synagoga, där fariséerna håller ögonen på Jesus: "de ville gärna ha något att anklaga Jesus för" (̊̊k3-4, 61). Härifrån kommer ju som bekant alternativen att göra gott/ont och rädda liv/döda på sabbaten. Fariséernas slutsats blir ju då att "röja Jesus ur vägen" (Mark 3:6) eller "döda Jesus" ( $\AA$ k3-4, 62). Studieboken inskärper allt ytterligare och uppmanar eleverna med pedagogiskt (?) nit ytterligare: "Rita en bildserie om vad fariséerna inte fick göra på sabbaten" ( $\AA$ k 3s, 72).

Vilka grupper som utpekas som Jesu fiender beror ju på vilken text man läser. Tar man Matt får man såväl översteprästerna som de skriftlärde och fariséerna. När Jesus förs till Stora rådet, anges $\mathrm{i}$ marginalen till grundboken att detta på Jesu tid var "judarnas högsta styrande och dömande myndighet. Det bestod av översteprästerna, de skriftlärde och De äldste" (Åk3-4, 69). När Pilatus vill frige Jesus heter det: "Men judarna hotade och sade, att han inte var kejsarens vän, om han gav Jesus fri" ( $\AA \mathrm{k} 3-4,70)$. Om man gör bruk av alla versionerna får man en kumulativ verkan: då är det inte bara översteprästerna och de skriftlärda som hetsar upp folkhopen, utan Pilatus förhandlar direkt med "judarna", som hos Joh. Här upphör alla distinktioner. Vi vet att detta sätt att framställa sakerna har haft ödesdigra följder just för - judarna!

Går vi vidare till fjärde årskursen blir intrycket detsamma; översteprästerna har ibland sällskap av den ena gruppen, ibland av den andra:

öp och de skriftlärda ( $\AA$ k3-4, 128.143); öp och och folkets äldste (Åk3-4, 150); öp och fariseerna ( $\AA \mathrm{k} 3-4,156)$; öp och deras anhängare ( $\AA \mathrm{k} 3-4,166)$;

Efter en så massiv negativ information hjäl- 
per det föga med mera saklig-positiv information av vad fariseer och skriftlärda var. Sådan ges visserligen $i$ årskurs fem $(\AA \AA k 5-6,18)$. Men om man skulle ha börjat sympatisera med dessa "lärda män som undervisade om GT:s böcker" och varav de flesta var fariseer, som i sin tur "menade, att Guds rike skulle komma om man höll lagen" ( $\mathrm{k} 5-6,18$ ), får man hastigt en knäpp på näsan: "Jesus visade, att förlåtelsen är en livsinställning till andra människor. Utan den liknar vi fariséerna på Jesu tid" ( $\mathrm{k}$ 5s, 29).

Sedan är det ju så att Jesu fiender också är Stefanus' och apostlarnas fiender ( $\AA$ k3-4, 170; Åk5-6, 78). Här ligger Apg till grund för historieskrivningen.

Problemet med denna bild av fariseerna och de skriftlärde, eller överhuvudtaget av folkets ledare, kan beskrivas i tre punkter:

1. Utgångspunkten är de nytestamentliga berättelserna vars inbördes diskrepanser inte noteras och vars källvärde aldrig tycks i frågasättas, t.ex. såsom tendentiösa/polemiska.

2. Även när det gäller beskrivningen av nytestamentliga händelser, ger man information om judiska grupper och förhållanden, som om ingen annan relevant information om judendomen på Jesu tid skulle finnas. ${ }^{4}$

3. Genom mycket precisa men samtidigt tendentiösa frågor och alternativ bibringas eleverna uppfattning-en att det ändå rör sig om faktakunskap.

\section{9-11. Jesus och Paulus som judar; missionen}

Det sägs aldrig direkt ut att Jesus var en jude. Att så var fallet kan man sluta sig till genom många andra uppgifter, börjande med att "Jesus tillhörde Israels folk" ( $\AA \mathrm{k} 1,101$; jfr $\AA \mathrm{k} 2,26$ ). Jesus gick i synagogan "eftersom det var sabbat" (Åk3-4, 55), "som han brukade på sabbaten" (Åk3-4, 61). Eleverna får t.o.m. uppmaningen "Föreställ dig att du följer med Jesus och hans familj till en synagoga" (Åk3-4, 120). Också i hemmet skall han ha undervisats "i folkets heliga skrifter" (Åk3-4, 123). Ännu i åttonde årskursen läser vi det positiva: "Också Jesus helgade sabbaten genom att besöka synagogan" $(\AA ̊ k 8,67)$. Så långt är Jesu judiska identitet helt klar och till synes oproblematisk.

Men dessa uttalande varvas ju med uttalanden om kritik både mot Jesus och från hans sida. Redan i ettans kurs heter det: "Men alla tyckte inte om Jesus. Några var arga på honom"
( $\AA \mathrm{kl}, 93)$. De skriftlärdas beslut att döda Jesus omtalas $\mathrm{i}$ andra årskursen ( $\AA \mathrm{k} 2,75)$, vilket sedan verkställs genom översteprästens och soldaternas försorg ( $\AA$ k2, 77). Att Pilatus inte kan driva sin vilja igenom mot "folkets ledare" sägs ju också i detta sammanhang. Jesus å sin sida

rent av chockerade sin samtid genom sin förkunnelse... och genom att $i$ handling visa att också de föraktade och utstötta, de sjuka och lidande, också kvinnor och barn var lika högt älskade av Gud som de som kände lagen och kunde leva ett oklanderligt liv efter den ( $\AA$ k9, 66).

Judarna ansåg t.ex. att man inte skulle umgås med moralisk tvivelaktiga personer, att man inte fick tala med en kvinna på en offentlig plats och att deras tempel var förmer än alla andra tempel. Läs Joh. 4 och ange på vilket sätt Jesus bröt mot dessa uppfattningar i samtiden (Åk9, 67).

Här har skolboksförfattaren inte beaktat att Jesus också enligt Joh 4:22 till den samariska kvinnan sade: "Ni tillber det som ni inte känner till. Vi tillber det vi känner till, eftersom frälsningen kommer från judarna". Varför skulle man utesluta den aspekten om man vill använda Joh 4 för beskrivningen av Jesu förhållande till sin samtid? Att sådana texter som Matt 10:5 om att de tolv inte skulle bege sig till hedningarna och inte gå in i någon samarisk stad helt förbigås, är inte ägnat att överraska. De skulle framställa honom som överraskande traditionell i sitt förhållande icke-judar. ${ }^{5}$ Paulus' judiska identitet framhävs nästan tydligare än Jesus:

Saulus (Paulus) föddes i staden Tarsus i Mindre Asien ungefär vid samma tid som Jesus. Hans föräldrar, som var judar, var romerska medborgare... Saulus gick först i skola i Tarsus och sedan i Jerusalem. Han kunde skriva och tala tre språk... Saulus var farisé och mycket noga med att hålla den judiska lagens alla bud och stadgar. Han var också skriftlärd... Saulus var jude och kunde inte tro, att den korsfäste Jesus var Messias, Guds son. Därför ville han utrota alla dem som spridde den läran. Han godkände, att Stefanus stenades, och han var närvarande när det skedde... Ivrigt började han sedan spåra upp Jesu lärjungar... Även i Damaskus ville Saulus söka efter judar, som hade blivit kristna. ( $\AA$ k5-6, 83f.)

Samtidigt som det slås fast att Saulus var en ärkejude - dvs farisé och därtill skriftlärd tycks läroboksförfattarna anse, att detta att han inte trodde att Jesus var Messias räcker att förklara, att han startar en förföljelsekampanj mot de judekristna. Det är historiskt lika diskutabelt, som att detta att alla "inte tyckte om" resp. "var arga" på Jesus $(\AA \mathrm{k} 1,93)$ och att han sagt att han var Guds son $(\AA k 2,75)$ skulle räcka som motiv till att vilja döda honom. 
Fastän orsakförhållandena inte direkt och explicit reds ut är detta ändå det intryck eleverna måste få - och härmed måste ju deras bild av fariseerna och de skriftlärde som Jesu oförsonliga fiender bli grundmurad. Bristen på historiskt perspektiv ersätts av traditionella men högst diskutabla förutsättningar. Det har visat sig vara ödesdigert förr och allt talar för att det är så ännu. Vad missionen beträffar omnämns missionsbefallningen enligt Matt 28 på flera ställen ( $\AA \mathrm{kl}, 99 ; 2,88 ; 3-4,162 ; \AA \AA \mathrm{k} 4 \mathrm{~s}, 68$ etc). Missionens avsikt anges vara att "berätta för andra människor om Jesus" (Åkl, 134; jfr Åk2, 88). Att missionen först riktade sig till judar framgår också ( $\mathrm{k}$ 5-6, 87f) liksom att "hedningar som blivit kristna inte behövde hålla den judiska lagen" $(\AA \mathrm{k} 5-6,92)$. Att missionen bland judar både hade framgångar (t.ex. Åk5-6, 94) men också stötte på motstånd och ledde till förföljelser framgår givetvis ur framställningen av kristendomens äldsta historia, baserad på Apg. Man kan inte säga, att skolböckerna är speciellt missionsorienterade. Det förefaller också klart, att andra religioner inte framställs "som bakgrund för missionsarbetet" $i$ enlighet med Handledningens anvisning $(\mathrm{Hl}, 12)$. Dock kan man fråga sig om inte framställningen av judendomen på Jesus och apostlarnas tid nödvändigt implicerar att kristen judemission var och förblir (?) något högeligen önskvärt.

\section{Judiska institutioner}

Här har vi att göra med ett pedagogiskt sett tacksamt material, man kan använda illustrationer. Vi har också i skolböckerna både tecknade skisser av synagoga och tempel. Jämförelser med av eleverna kända institutioner såsom skola och kyrka ligger nära till hands. Också funktionerna och funktionärerna kan presenteras på ett relativt lättillgängligt och korrekt sätt. Det faktum att Jesus alltsedan barnsben besöker tempel och synagogor, gör ju också att dessa institutioner i sig inte ter sig främmande. Något obegripligt blir det $\mathrm{i}$ alla fall att Jesus började välta "växlarnas bord och duvomånglarnas säten". och säger att de gjort templet till en rövarkula ( $\AA$ k3-4, 65). Här är tanken att det rör sig om en "tempelrensning" en outtalad tolkning, som läroboksförfattarna kan få bekräftad av bibelforskarna. Jag vill dock hänvisa till det av E.P. Sanders gjorda påpekandet att der rörde sig om helt legitima och nödvändiga ting att växla till rätt valuta och köpa felfria offerdjur, varför man måste fråga sig varifrån templet under dessa omständigheter måste rensas. Är det inte snarast så att Jesus med sitt handlingssätt ville symbolisera templets förstörelse och att detta bättre skulle förklara att han fick motståndare inte bara bland tempelhierarkin utan också bland vanliga tempelbesökare (E.P. Sanders, Jesus and Judaism, 1985, 69f; 89f)? Men här vill jag ingalunda kritisera läroböckerna!

Några problematiska eller felaktiga uppgifter om judiska institutioner ges i alla fall. När det $i$ studieboken för årskurs 3 heter "Pengar till templet fick man genom tempelskatt, som varje vuxen judisk man måste betala" ( $\AA \mathrm{k} 3 \mathrm{~s}, 75)$, så överdrives nog tvånget. Läroböckerna vet också mera om Stora rådets rätt att döma Jesus ( $\AA$ k $4 \mathrm{~s}$, 65.89) och Stefanus ( $\AA \mathrm{k} 3-4,169)$ till döden, än vad man inom forskningen tror sig veta. En tendens att spela ut judisk och kristen gudstjänst mot varandra kan också noteras på ett ställe:

synagoga judisk gudstjänstlokal, där bokrullarna med de heliga skrifterna förvarades $i$ en kista av cederträ. På sabbaten var det gudstjänst i synagogan. Minst tio män måste vara närvarande. Jämför med Jesu ord i Matt. $18: 20$ "Ty där två eller tre är församlade i mitt namn..." (Åk5-6, 16).

Ävenom jag alltså bedömer framställningarna på denna punkt som övervägande sakliga och riktiga, nödgas jag konstatera, att litet av den gamla "surdegen" från de tendentiösa framställningarna av lagen och tvånget inom judendomen fortfarande finns kvar. Dock skulle det härvidlag räcka med en översyn av annars goda beskrivningar.

\section{3-14. Antijudaism, antisemitism och "holocaust"}

Här kommer informationen först $i$ sjunde årskursens specialavsnitt om judendomen. Först konstateras helt sakligt och nyktert:

År 70 e.Kr. förstördes Jerusalem och den kvarvarande befolkningen spreds över stora områden. Ofta utsattes judarna under de kommande århundradena för förföljelser $(\AA \AA \mathrm{k} 7,32)$

Likaså nyktert och mera i förbifarten konstateras: "Under andra världskriget hade c. 6 miljoner judar avrättats och det bidrog till viljan att lösa judefrågan med tanke på framtiden" ( $\mathrm{k}$ 7 , 33). Ordet "avrätta" låter i mina öron som en eufemism, när det gäller "holocaust" och kan i 
värsta fall suggerera föreställningen att något rättsligt förfarande hade föregått "avrättningen". Mera utrymme för känslorna ger Pavel Friedmans dikt från Theresienstadt 1942: Eleverna uppmanas diskutera vad han ville säga med den. Jag läser den på det sättet att han vill säga farväl till naturen, grönskan och fjärilarna, som han vet att finns utanför ghettot. Och det är något som en tonåring mycket väl kan leva sig in i.

På tal om lidande, sägs i nionde årskursen ännu något:

En del av lidandet uppkommer genom att människor medvetet tillfogar varandra skada. Det kallas moraliskt ont. Lidandet kan i denna form begränsas till en enda människa, men det kan också drabba hela folk som fallet var med judarna under andra världskriget. $(\AA \AA$ k9, 18)

Detta är också allt vad grundskoleleverna får läsa om något som ändå hör till den västerländska civilisationens stora skamfläckar. Med tanke på den ofta ej heller förklarade information som möter om "holocaust" på TV-skärmen frågar jag dock, om det inte vore befogat att ge sig i kast med uppgiften att reda ut orsakerna och rötterna härtill i det "kristna västerlandets" historia. Detta så mycket mera som antisemitismen är en variant av det främlingshat som vi i Norden också idag kommer i beröring med. Bortsett från att antisemitismen ännu lever mitt ibland oss! ${ }^{6}$

\section{Sionismen och staten Israel}

Som jag nämnde under p. 1 om "landet" introduceras det moderna Israel här och var redan $\mathrm{i}$ framställningen av den bibliska historien ( $\AA \mathrm{k} 2$, $25 ; 3-4,11.22 ; 3 \mathrm{~s}, 48.57)$. Direkt undervisning om staten ges dock först $i$ avsnittet om judendomen i årskurs 7:32f. 36:

År 1896 skrev T. Herzl sin berömda bok om den judiska staten (Der Judenstaat). Upprättandet av Israel som ett hemland för judar år 1948 făr ses som ett resultat av sionismen. Det var en nationell rörelse som uppkom genom studiet av Herzl's bok... Också självständighetstiden har för judarna inneburit en ständig kamp för frihet och oberoende. Man har bl.a. utkämpat flere krig med araberna. Frågan om palestiniernas rätt till ett eget land är alltfort det stora hindret för bestående fred./Av judarna, som uppgår till c. 15 miljoner, bor två miljoner $\mathrm{i}$. Israel och sex miljoner i USA. De övriga judarna bor på olika håll i världen, bl.a. i Sovjet.
Trots den sakliga och i stort sett riktiga framställningen, bör åtminstone två saker rättas till: sionismen uppkom helt säkert inte av att man läste Herzl's bok. Både rörelsen och t.o.m. ordet fanns ju tidigare. Att det skulle bo bara $t v a ̊$ miljoner judar i Israel är en starkt föråldrad uppgift - tre bör det vara.

Eleverna uppmanas ytterligare i grupper diskutera på vilket sätt man kunde lösa problemet med freden, "så att man beaktar både judarnas och palestiniernas rätt till eget land"' ( $\AA \mathrm{k} 7,37)$. Bland ordförklaringarna i slutet av boken ges ännu "sionism judisk nationell rörelse" ( $\mathrm{k} \mathrm{k} 7$, 91). Det är allt.

Materialet på dènna sista punkt i min undersökning kan sägas vara knapphändigt. Man bör beakta, att staten Israels existens och aktualitet $i$ massmedia gör en anknytning naturlig på de mest olika ställen $\mathrm{i}$ religionsämnets kurser. Sådana anknytningspunkter finns också direkt i kursböckerna och anknytningarna kan säkert göras av initierade lärare och elever, som kanske besökt landet. Kursböckerna är ju sist och slutligen medel och inte mål. Under sådana omständigheter riktas intresset mot läroplanerna och handledningarna.?

\section{Sammanfattning och slutsatser}

Jag vill sammanfatta min undersökning på följande sätt:

1. Det undervisas "tematiskt" om judendomen endast $i$ årskurs 7 . Härtill får man dock lägga det material som används $i$ undervisningen om bibeln. Här kommer en hel rad judiska termer, seder och institutioner explicit upp. Även om det mest handlar om "judendomen på Jesu tid" innebär allt detta också undervisning om judendomen.

2. Kursböckernas stoffurval och även framställningssätt regleras av läroplanerna. En del traditionella uppfattningar ifråga om förhållandet mellan GT och NT, speciellt när det gäller gudsuppfattningen och etiken kommer fram i läroplaner och lärarhandledning. Delvis hänger detta samman med att vi har konfessionell religionsundervisning. På det hela taget kan man sẳga, att böckerna ganska väl svarar mot de mål som läroplaner och handledning uppställer för undervisningen om såväl bibeln som judendomen, som en annan religion. 
3. En hel del positiv och riktig information ges både om den antika ("på Jesu tid") och moderna judendomen, även om den senare på grund av läroplanen får ett mycket knappt utrymme. För eleven positiva anknytningar till Jesus som jude görs.

4. De största bristerna $\mathrm{i}$ undervisningen om "judendomen på Jesu tid" ligger kanske däri att läroböckerna parafraserar nytestamentliga texter, som sinsemellan ger olika informationer och dessutom ofta är att betrakta som tendentiösa i sin framställning av t.ex. Jesu "fiender" eller motståndare. Även om det ligger i det konfessionella kristna perspektivet att ge just evangeliernas syn på saken, tycks läroboksförfattarna här inte ha reflekterat över det faktum att de samtidigt undervisar om en annan religion, judendomen, och att de nytestamentliga källorna om den samtida judendomen är både motstridiga och ofta tendentiöst karikerande.

5. En mycket problematisk skärpning av ovanstående tendenser åstadkoms i några av studie- eller arbetsböckerna, som genom precisa frågor och alternativ - säkert i bästa välmening - försöker mejsla fram "fakta" om t.ex. fariseerna och de skriftlärda.

6. Ovanstående strider enligt min mening mot målsättningen att framställa andra religioner och i detta fall judendomen i "positiv varm anda". Givetvis fanns det motsättningar mellan Jesus och en del av hans samtida och detta bör självklart komma fram på ett sakligt riktigt sätt. Samtidigt har bibelforskningen också övertygande visat att en hel del av dessa motsättningar och framför allt det sätt på vilket evangelierna återger dem måste vara resultatet av den polemiska situation som uppstod ca 40-50 år efter evangeliernas händelser. Det beror på den enkla omständigheten att evangelierna fick sin form vid en tidpunkt då kyrkan och synagogan gick skilda vägar och då häftig polemik fördes frän vartdera hållet. Det rör sig här inte om några nya vetenskapliga rön utan om ett historiskt perspektiv som borde få komma till sin rätt också vid utarbetandet av läroböcker för grundskolan.

7. De största bristerna har jag funnit i kursböckerna för åk 3-6 och arbetsböckerna för åk 3-5. Jag rekommenderar, att de utmönstras ur skolboksmaterialet så fort lämpliga ersättningar finns att tillgå. Att jag härvid inte slår in öppna dörrar, framgår av det faktum att de godkänts för användning så sent som i mars 1985. Samtidigt noterar jag med tillfredsställelse att nya läroplaner är under arbete hos Skolstyrelsen. ${ }^{8}$ Detta leder med nödvändighet till att också läromedlen åtminstone måste ses över och i många fall även ersättas med nya.

8. De övriga böckerna som jag haft med i min undersökning, dvs. de som används för åk 1-2 och åk 7-9, uppvisar också en del brister, men av sådant slag att jag skulle nöja mig med en översyn för kommande nyupplagor. Härtill kommer den omständigheten, att det till dessa böcker finns alternativ också på svenska. Jag har ej haft möjlighet att få med alternativen i denna undersökning, men anser det viktigt att sådana finns. Beträffande alla läromedel hoppas jag att de kommande nya läroplanerna, skall ge anledning inte bara till en minimal översyn. Vad som behövs är ett fruktbart samarbete mellan pedagoger å ena sidan och experter på bibelvetenskap och judaistik à den andra - och det över hela linjen alltifrån läroplaner och handledningar till läromedlen. Jag vågar hoppas 'på detta inte minst efter den sakliga och positiva respons jag fått på mitt föredrag - av läroboksförfattarna!

\section{NOTER}

1. Se Bertel Wahlströms och Teuvo Virtanens artiklar i detta $\mathrm{nr}$.

2. En del av materialet i denna bok är hämtat ur en finskspråkig motsvarighet, nämligen Uskonto ja me 8 av L. Peltola, M. Mäkituuri, R. Turtola och R. Peltola.

3. En för nordisk läsekrets tillgänglig presentation av Finlands nu gällande skollagstiftning och dess inverkan på skolundervisningen i religion ingår Ekumenisk orientering 1985:1-2 utg. av Nordiska Ekumeniska Institutet (Sigtuna, numera Uppsala).

4. En lättillgänglig handbok är Hans Kvalbein (red), Blant skriftlarde of fariseere. Jødedommen $i$ oldtiden. Verbum Forlag, Oslo 1984. Boken recenserades av mig i denna tidskrift nr 1985:2.

5. Dessa exempel visar enligt min mening, att man vid utarbetandet av läromedel redan för grundskolan inte kommer förbi frågan om vad som är historiskt riktigt och vad som inte är det $\mathrm{i}$ evangeliernas bild av Jesus och hans förhållande till sin samtid. Varken läroboken som sådan eller läraren i klassen kan rimligen förväntas gå in på 
dessa spörsmảl. Valet av textmaterial och presentationen av det görs av läroboksförfattaren. När texter rent av $\mathrm{i}$ samma kapitel tycks peka i direkt motsatt riktning bör man fräga sig vilken text av dessa som historiskt sett kommer närmast sanningen.

6. Också här vill jag hänvisa till en utmärkt ny bok: Leo Eitinger, Mennesker blant mennesker. En bok om antisemittisme og fremmedhat. Cappelens Forlag. Oslo 1985. Recension följer längre fram $i$ detta nummer.

7. Om det förhåller sig så, att läroplanen inte medger större utrymme om t.ex. sionismen och Israel, blir lärarens roll som kunskapsförmedlare desto viktigare. Också på denna punkt vill jag ge ett boktips: Per Bilde \& Peter Steensgaard (red), Zionismen og Israel. Religion - ideologi - stat belyst ved det moderne Israel som eksempel. Forlaget
Aros. Århus 1983. Anmäld av mig i denna tidskrift nr 1985:2. Men hur skall skolans mål att fostra till internationalism kunna förverkligas, om inte läroplanerna ger mera utrymme åt relevant information om t.ex. Främre Orienten? Och här har religionsundervisningen en nyckelroll tänk också på den moderna islam och dess förhållande till sionismen och Israel!

8. Beträffande godkännadet av de nämnda böckerna "för fortsatt användning" kan jag hänvisa till Skolstyrelsens resolution av den 6.3.1985. Beträffande de kommande nya läroplanerna hänvisar jag dels till muntlig information som jag fått från lärarhâll, dels till $\mathrm{H}$. Juntunens artikel "Religionsfostran i den nya skollagstiftningen" $i$ ovannämnda (se not 3) nummer av Ekumenisk orientering, s. 9. 